\title{
The southern highlands from Gourock
}

\author{
Frederick Mort M.A., B.Sc., F.G.S. \& John Frew M.A.
}

To cite this article: Frederick Mort M.A., B.Sc., F.G.S. \& John Frew M.A. (1906) The southern highlands from Gourock, Scottish Geographical Magazine, 22:8, 435-438, DOI: $10.1080 / 00369220608733658$

To link to this article: http://dx.doi.org/10.1080/00369220608733658

曲 Published online: 27 Feb 2008.

Submit your article to this journal $\pi$

Џlll Article views: 4

Q View related articles $\sqsubset$ 


\section{THE SOUTHERN HIGHLANDS FROM GOUROCK.}

By Frederick Mort, M.A., B.Sc., F.G.S., and John Frew, M.A.

\section{(With Figures.)}

IN the June number of this Magazine we gave and described drawings showing the aspects of the Southern Highlands from Dumgoyn, a hill in the north of the Clyde valley. If the observer changes his position to the south of the Clyde, he obtains quite a different view of the Highland peaks. The point from which the accompanying drawings were made is a hill about two miles south-west of Gourock. It is the 610 feet summit level shown on the ordnance maps just behind Leven Castle. From this point a magnificent sweep of coast-line can be observed, stretching from above Helensburgh, past Dunoon, to Toward Point. South of Toward Point, one looks right over Bute to Arran in the distance.

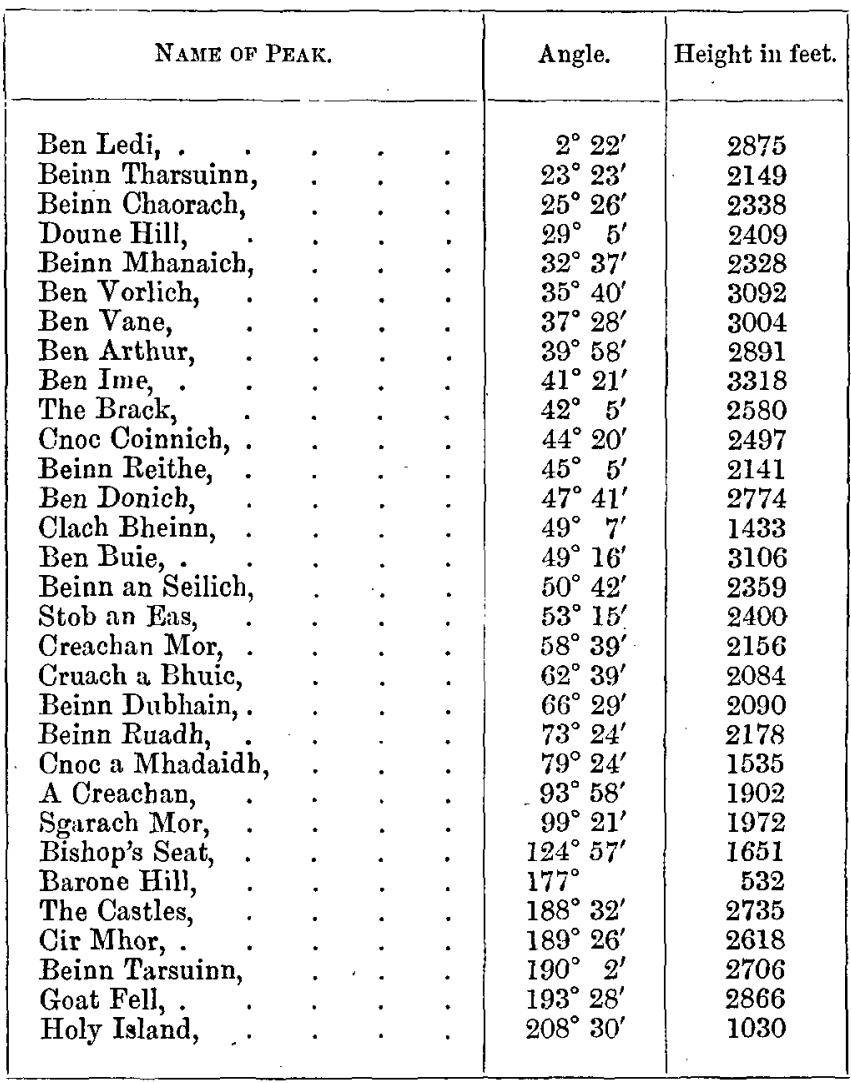

As before all the angles shown were taken with a theodolite, and the contours of the hills are accurately copied from photographs. The true 
angular relations of the various peaks and ranges are shown in Fig. 1.

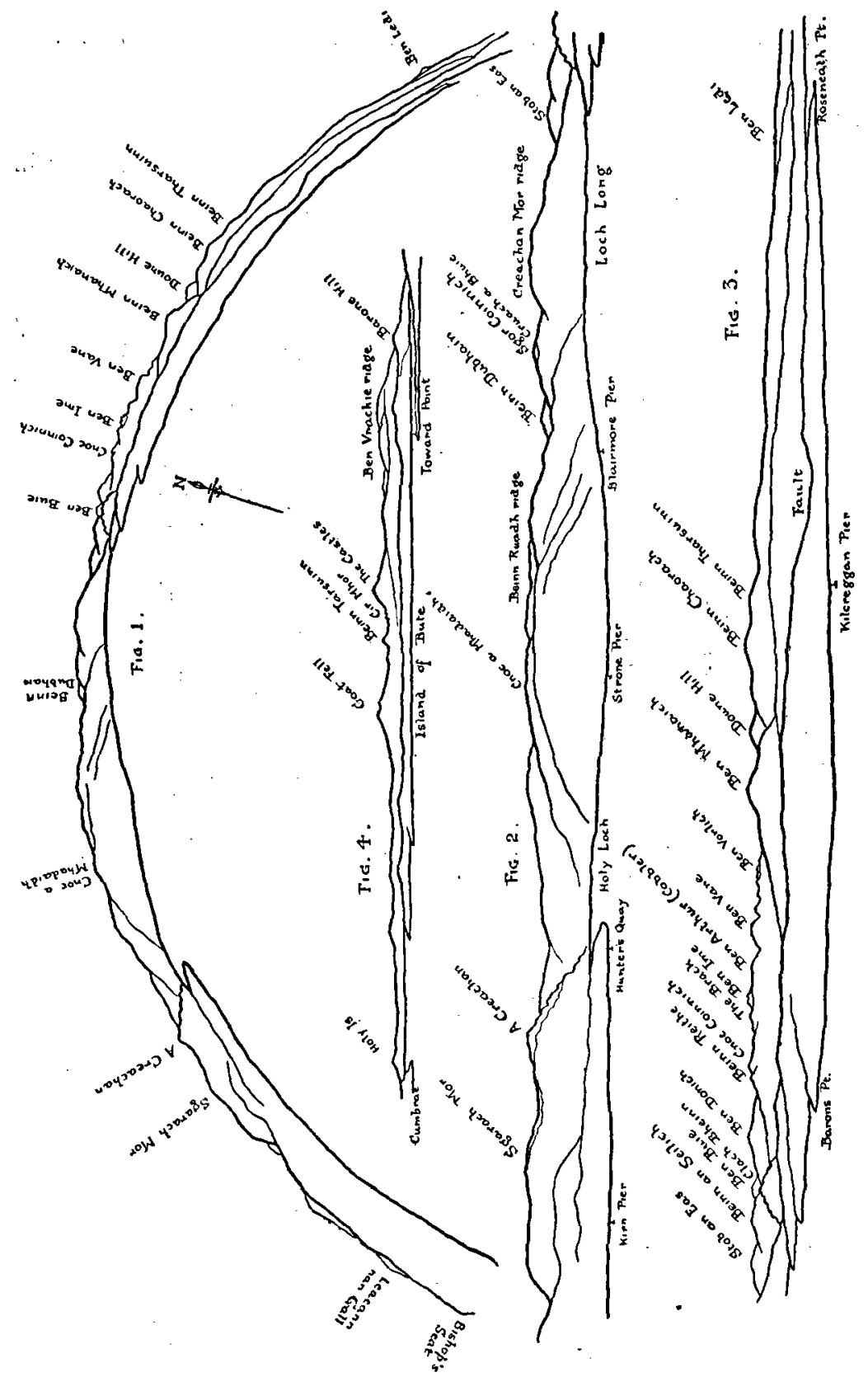

The skyline of the observer is, of course, circular, and the observer's 
position is the centre of the circle of which Fig. 1 is an arc. In order to obviate confusion in the drawings, we give the angles and heights of the various peaks in the foregoing table. All angles are measured from Roseneath Point.

Figs. 2 and 3 show the same hills as Fig. 1, on a scale about twice the size of that of Fig. 1.

The ridge from Bishop's Seat above Dunoon to Glen Lean in front of Sgarach Mor, is omitted in Fig. 2, as Bishop's Seat is the only feature of any importance. The most interesting mountain group shown in the drawings is undoubtedly the range behind Loch Long. Although few of the summits exceed 3000 feet in height, the mountains are so rugged in outline, the masses so justly proportioned, and the contours so varied, that they form as impressive a group as any in the country. The range subtends an angle of only $14^{\circ}$, but to the observer the mountains give the impression of stretching over a much greater extent.

of this group of mountains, sometimes termed the "Alps of Arrochar," the highest and most imposing is Ben Ime. Both Ben Ime and Ben Vorlich are in the background, as is shown in Fig. 3. The line of the ridge just in front of them is shown in the drawing, but it may be quite imperceptible to the eye. Such also is the case with several other lines in the drawings. It is only in certain lights that they become visible. For example, on only one day of the three that we spent on the hill-top was it quite plain that Ben Reithe and Cnoc Coinnich were two distinct peaks, and not one. Of the two hills, Clach Bheinn and Ben Buie, Ben Buie is, of course, the more remote. Clach Bheinn is interesting, for it forms the most southerly and best known point of Ardkinglas, the estate just presented to Glasgow for the benefit of the citizens. Most of the important Perthshire mountains are completely cut off by the high ridges in the foreground. It is only where these diminish towards the east that Ben Ledi becomes visible.

One of the most interesting features of the landscape is seen in the drawings just east of Kilcreggan Pier. A distinct notch cuts into the low range of hills behind Kilcreggan. This is the groove caused by the great fault that runs right across Scotland. This great crack separates the Highlands from the Lowlands, all the rocks to the north belonging to the Highland schist series.

No one can fail to be struck by the great differences of outline of many of the ridges. All the foreground is occupied by low ranges of smooth and rounded contours, the profiles of which sweep down in softly flowing curves to meet the sea. From A Creachan behind the Holy Loch, however, over Ardkinglas estate right on to Ben Vorlich, the ranges are altogether different. Rough and gnarled, with jagged and serrated peaks, they form an ideal background to one of the finest views in Scotland. The explanation of this striking contrast is not difficult. The rocks in the foreground are comparatively soft and therefore weather with rounded outlines. Behind them there runs from south-west to north-east a band of hard, tough, pebbly grits which by their weathering give rise to the imposing outlines of Argyle's Bowling Green and the "Arrochar Alps." The district is also traversed by numerous lines 
along which considerable crushing has taken place. The broken rock is easily removed by weathering and the resulting features add largely to the tumbled, rugged appearance of this area.

The old Highland platean can be splendidly seen from the high ground behind Greenock or Gourock. Sir Archibald Geikie in The Scenery of Scotland recommends the hills behind Greenock as one of the best spots from which to obtain a good view of the Highlands. A glance at Figs. 2 and 3 shows that a ruler could almost be laid right along the tops of the mountains. As we pointed out in our last paper, the mountains are merely the last remuants of an old table-land.

In Fig. 4 Arran is shown on exactly the same scale as Figs. 2 and 3. Its insignificant size is of course due to its much greater distance. In the foreground the Island of Bute is seen. Looking at its true proportions (the vertical scale is the same as the horizontal) it is not difficult to understand how, at one time, the glaciers from the galhering grounds in the north flowed completely over Bute. The drawing is instructive in showing the marked contrast between this view of Arran and the much more familiar one from the east. With the latter view in the mind's eye, the distance of Holy Island from Goat Fell is rather surprising. Owing to the greater distance of Goat Fell from the point of observation, it is dwarfed both in height and bulk by the main peak of the Castles. Although the serrated outline of the skyline at Cir Mhor seems quite continuous, the peaks forming the notches there are really at very different distances from the eye.

\section{GEOGRAPHICAL NOTES.}

\section{EUROPE.}

Earthquake in South Wales.-An earthquake shock was felt on June 27 over a large area extending from Flintshire on the north to Plymouth on the south; and from Pembrokeshire on the west to Bath, Bristol, and Birmingham on the east. The length of the tremors is variously given as from two to ten seconds, and although a good deal of alarm was caused, especially in the mining districts of Glamorganshire, no serious damage is reported.

At Cardiff the shock was felt at about 9.50. It was preceded by a noise like the rumbling of a passing train, and lasted from eight to ten seconds. The severest tremors were felt at the docks.

At Swansea at 9.44 the people were alarmed by a noise as of a tremendous explosion, and this was immediately succeeded by a violent shock, which lasted two seconds. Pediments fell from the General Post Office and other public buildings, and hundreds of chimneys collapsed, some through roofs and others on to the pavements. In some of the streets the fall was so abundant that cartloads of bricks had afterwards to be removed. It was remarkable that, notwithstanding the widespread fall of débris at a time when the streets were full of people going to business, there was no case of serious injury. 